\title{
Effect of Work Stress on Work Life Balance: Moderating Role of Work-Life Support Organizational Culture in Sri Lanka Customs Department
}

\author{
T. D. Weerasinghe ${ }^{1}$ and M. G. D. Dilhara ${ }^{2}$ \\ ${ }^{1}$ Department of Human Resource Management, Faculty of Commerce and \\ Management Studies, University of Kelaniya, Sri Lanka \\ tdtmdananjaya@gmail.com / tharindu@kln.ac.lk \\ ${ }^{2}$ Sri Lanka Customs Department, Colombo, Sri Lanka
}

\begin{abstract}
This study was initiated with the primary objective of assessing the impact of work stress on work-life balance of custom officers serving for the Sri Lanka Customs Department. Further, to assess the moderating role of 'work-life support organizational culture' in the said context it was established as a secondary objective. The study is a basic research in which the researches attempted to answer a problem that is concerned with filling a contextual gap in the empirical knowledge. Deductive approach was predominantly applied, and the study is mainly explanatory. Hence, this was carried out as a cross-sectional, quantitative field-study among a sample of, randomly selected 200 custom officers. Primary data was collected through a standard questionnaire which has met the accepted standards of reliability and validity.

It is found that work stress has a significant negative relationship $(r=-0.695)$ with work-life balance of custom officers. The direct impact $\left(r^{2}=.476\right)$ of work stress on work life balance is also statistically significant (sig $=0.000)$ and which is further moderated $\left(r^{2}=.481\right)$ by the prevailing culture in the context. Moreover, the culture in Sri Lanka Customs is identified as a work-life support culture in which employees are empowered adequately to manage multiple roles in their lives, though the job is highly stressful. So that, it is recommended to encourage and maintain such a culture continuously in the Customs Department to help employees to manage multiple demands and expectations deriving from rest of life other than work. Further, it is suggested that the policies and initiatives put
\end{abstract}


forward to facilitate employees' work-life balance in the organization to be reviewed and appropriately modified frequently, aligning with the organizational culture to obtain the maximum outcomes from such policies and initiatives.

Keywords: Work stress; work-life balance; work-life support organizational culture; Sri Lanka Customs Department

\section{Introduction}

In the past three decades, a higher degree of the focus of social research was given to the study of underlying relationships among work and rest of the life of working people; employees (Clark, 2000; Chan et al., 2015). Such studies have shown that the lack of balance in person's life is related to higher turnover, less productivity, and lower work effectiveness (Clark, 2000). Not surprisingly, employees are generally ready to sacrifice their rewards or even change the organization with the prime purpose of achieving a better work-life balance (Galinsky, Bond \& Friedman, 1993 as referred in Lambert et al., 2008).

Similarly, work stress is an impressive theme which has been widely researched and reported for a considerable period of time in the last three decades. Work stress is an ecological scenario in which an employee is required to perform a certain work that exceed his/her capacity and resources for accomplishing it. Stress arises under conditions where people expect a huge gap in compensation from meeting the target versus not meeting the target (Berry, 1997). Accumulated work stress is very much harmful to employees as they will react by trying to disregard it by removing either mentally, physically, and emotionally or by leaving the job entirely (Dupre \& Day, 2007). Further, research on work stress suggest that it has negative outcomes for individuals such as higher work-life conflicts (Anderson, Coffey \& Byerly, 2002 as cited in Lambert et al., 2008) and increased work-life imbalance.

One of the current researchers is a customs officer serving the Customs Department of Sri Lanka, and it has been observed that many of the customs officers are suffering from work-life balance issues. Also, due to the work roster, rotation among various geographical regions including; Katunayake, Galle, 
Trincomalee, Jaffna, Hambantota, and the endless night shifts officers are under stress even though they can get a quite considerable level of financial rewards. Researchers conducted structured interviews with randomly selected six custom officers to collect preliminary evidence to justify the problem. All of them have replied in the same way saying we are under stress and experience work-life balance problems.

Though the direct impact of work stress on work-life balance is recognized, however, theoretical discussion on that and previous research findings of the association among those two constructs is not consistent across all the domains, and much remains to be discovered. (Lambert et al., 2008; Chan, et al., 2015). It is recognized that a relatively fewer number of studies tried to discuss the impact of work stress on work-life balance, from the perspective of custom officers. Among such previous research studies which attempted to establish the association between work stress and work-life balance in different countries, only a few were conducted in Sri Lanka. Hence, having considered the aforesaid situation the below mentioned problem is raised in the present study to be investigated with empirical data collected from the Sri Lanka Customs Department.

What is the effect of work stress on work-life balance of custom officers, which is moderated by the work-life support organizational culture in Sri Lanka

\section{Customs Department?}

The primary objective of this research study is to assess the impact of work-stress on work-life balance of customs officers those who are currently working for Sri Lanka Customs Department. Moreover, to recognize and assess the moderating role of work-life support culture in the Customs Department, on the association between work stress and work-life balance was established as the secondary objective. 


\section{Significance of the study}

Accordingly, this research addresses the gap in management and social research examining the effect of work-life support organizational culture in explaining work-life balance of employees, especially in the domestic context. Consequently, the study would bridge the contextual gap in Sri Lanka Customs Department up to a significant extent. Also, this study would make a major practical implication by investigating the moderating effect of work-life support organizational culture which has not been taken into account to discuss the impact of work stress on work-life balance in research literature.

Additionally, this study will address the lacuna in Job Border Theory (JBT) of Clark (2000) in which having a separate border between job and the life is recommended. However, customs officers don't have a border like that. Instead, they have a blended life; not a separate work life and a family life. So, the Job Border Theory is not adequate to explain the work-life balance scenario of custom officers. Hence, having a greater degree of theoretical significance the current research would provide insights to extend JBT. Further, the current study highlights the significance of creating and maintaining a sound work-life support organizational culture in the corporate atmosphere as an essential pre-requirement.

To obtain the maximum benefits from a work-life initiative, it is essential to identify the organizational culture first, to which all such policies must congruence with. Having understood that, this study will provide insights for decision makers and practitioners in organizations other than Sri Lanka Customs to fix work arrangements, and especially to execute work-life support initiatives in their respective work places according to the prevailing culture. Also, this study will provide insinuations for the state authorities and officials by providing insights into employment and policy making process of relevant state-owned business organizations. Hence, this research study has a sound theoretical, practical and policy significance for many stakeholders in the context. 


\section{Literature review}

Ernest \& Jama (2011) and Guest (2001) investigated the negative relationship among job stress and work-life balance of physical education teachers in Greece. Job stress significantly correlated with high work-life imbalance and higher tendency to leave the job among government officers in European countries (Steven, Ngo \& Tsang (2010) as cited in Ernest \& Jama (2011). Further, Gruneberg (1979) mentioned that stress can be exacerbated by organizational factors, such as: a long working day, radical organizational changes and lack of organizational support, minimum support from leaders and peers, and conflicts with demands for roles and role-playing.

Furthermore, Wickramasinghe (2012) identified and defined work stress as an unfavorable reaction of people when they have excess pressure put on them at work. Larson (2004) stated that job stressors may refer to any attribute of the workplace which creates a threat to the employee. For stress to exist, the demand from the job (including working environment) versus the capability of the employee will probably mismatch. In addition, stress is due to many factors that affect the employee, so that he/she is confronted with stress in his/her work. One of the most important factors that influence work stress is work demands and time demands which in turn negatively affect the work-life balance of a working person (Opatha, 2015). In simple terms it means, when two stressors; work demands and the time constraints are active, an employee has to select one domain at the cost of the other domain which hinders the balance between work and life. Hence, in any form stress will affect the work-life balance of people who are employed.

One expectation of implementing sound Human Resource Management (HRM) practices in a workplace is to facilitate workers at different life stages, with respective life responsibilities to enjoy a healthy and prosperous life. Thus, any management should implement initiatives to help the achievement of organizational targets, but not at the cost of workers' personal targets (Opatha, 2015). It means none of the employees need to sanctify his/her personal growth due to working in a particular organization. If it happens either employee or the employer is not conscious about work-life balance. So that, the expression work- 
life balance highlights that the demands of the job/work ideally should not hinder the private life of the worker. Weerasinghe and Batagoda (2012) mentioned that:

“...everyone has a life; work is not the life. What is work? It is just a part of life. None of us come to work to die; but to live..."

On one hand, Brown, et al. (2004) identified that few factors such as: number of global workplace, increased number of women entrants into the world of work, dual-career couples with no children, single parent families, and increased tendency of eldercare responsibilities; issues in job security (say there is no life time jobs now, job hoping itself is the passion of the new generation); and a distorting of work-life boundaries due to technological advancements due to which it is hard for a modern working person to achieve work life balance. Many of those factors are work place related stressors. On the other hand, employees might burn-out as a result of this imbalance. Burnout is identified and defined as a state of physical, psychological and emotional exhaustion as a result of accumulated work stress (Maslach \& Leiter, 2003).

Similarly, work-life balance indicates an individual's focus across different life roles (Marks \& MacDermid, 1996). Unlike the prevailing view which says that a person could organize his/her life, in this hierarchy of priorities, Marks \& MacDermid (1996) argued that employees could portray positive engagement even in diverse life roles; which is in simple terms, one could essentially hold a balanced focus/attention on multiple roles.

Any description of Work-Life Balance (WLB) includes two elements of equality: input and output. The inputs are the own resources; might be time, energy, money, relationships. (Kirchmeyer, 2000). Further, there are different types of such balance easily identified within a person. Positive balance suggests a higher degree of attention, time and engagement, while negative balance refers to a low degree of involvement in such domains. Indeed, inputs indicate an individual's level of role engagement in terms of 'time devotion' and 'psychological involvement' in demands of multiple roles in the life. The other element of this balance refers to the resulting experiences in work and life domains. Ideally, the major outcome 
earned form this balance would be the long term happiness in life (Clark, 2000). Positive balance implies a higher degree of satisfaction with work and life roles where negative balance suggests a lower degree of life satisfaction derived from those multiple roles. It means the person is not appropriately balanced.

Greenhaus et al. (2003) identified WLB as the degree to which an employee is appropriately engaged in, and as a result, contented with own life domains. Complying with Marks \& MacDermid (1996), this definition also considers the positive balance and the negative balance. Greenhaus et al. (2003) identified three (03) dimensions of work-life balance. They are:

Time balance (input balance): the extent of time devotion to multiple roles; Involvement balance (input balance): the extent of psychological bond with multiple roles; and Satisfaction balance (output balance): the extent of happiness a person gets by balancing so called multiple roles.

According to Greenhaus et al. (2003) to obtain a proper balance among work and life one must keep a tradeoff between inputs and the outcome. Also, to obtain a proper work-life balance one should exercise a proper combination of the above three elements occasionally. In one situation time balance might be more important, but in another different situation involvement balance might be more important. According to the stress theories and motivation theories (as argued by Clark, 2000) a person should compare his/her inputs and the outcome of satisfaction of particular situation to judge the cost and the benefits of work-life balance. However, that methodology is more technical in practice as it is very hard to quantify everything in life.

Work-life balance is highly a subjective, self-defined level of wellbeing that an employee can reach, or can set as a target, through which the person is empowered to manage multiple roles effectively (Clark, 2000). It supports the creation of health, wealth, enjoyment and prosperity. It is all about living in a contented full life both inside and outside of the paid employment. Work life balance does not reach when the work and life domains are very heavy or very light (Clark, 2000). As mentioned earlier, work-life balance is not about an equal balance on both 
domains. Sometimes imbalance might occur even because of not working or not engaging in a productive business; either personal or organizational. Thus, the conclusion would be, work life balance is a productive equilibrium a working person should reach on which all the other decisions relating to health and success will be accomplished (Guest, 2001).

Bailyn (1993); Galinsky \& Stein (1990); Regan (1994); Caudron (1997) as cited in Thompson et al., (1999) recognized the significance of having a work-life support organizational culture in an organization. Thompson et al. (1999) defined culture of life support as common norms, beliefs and values that the organization supports and appreciates the integration of the work of employees and life. Similarly, Thompson et al. (1999) discovered three key elements in a work-life support organizational culture. They are: corporate demands on working time \& engagement and expectations about work and the family to be; career consequences associated with trying to achieve a balanced life; and managerial understanding, support \& sensitivity to employees' life and family responsibilities.

Culture in a work environment could possibly ensure that employees/workers can have alternative options that take their family life into account without skipping their career progression. Clark (2000) also found that organizational culture is most often linked with the employees' work-life balance. As Clark (2000) mentioned it is broadly associated with life well-being of a person; because culture is everything. Beauvais \& Kowalski (1993) discovered that organizational culture based on working life is negatively associated with the conflict between work and family, and as mentioned by Francesco \& Thompson (1996) the culture of life support was positively (favorably) associated with life's happiness, which in turn positively affects the achievement of organizational goals. Likewise, McNall et al., (2010) found that when employees perceive that their respective work culture is supportive and comfortable in balancing multiple demands in the life as a result such employees will respond more proactively by elaborating the potential level of loyalty, engagement and commitment at work. Hence, the way employees perceive the culture in comparison to the scarifications of rest of the life in utterly 
significance (Clark, 2000) as it affects today to retain talented employees. So, the current researcher would conclude the debate afore-presented as: helping employees to live with the work, rather than continuously getting their engagement only for the work, will help to retain the high talent with the modern organizations.

Hence, it seems that there are enough evidence to argue a relationship among work-life support organizational culture and the work-life balance. Clark (2000) mentioned that underline causal relationships among work-life support organizational culture and work-life balance is not perfect and clear in historical findings. Further, Clark (2000) suggested that a construct like culture should be a moderator in a relationship. Hence, as a part of the contribution of the current researcher, work-life support organizational culture is taken as a moderating variable in the current study.

Having considered the theoretical explanations and empirical evidence in extant literature reported above, building on the Job Border Theory and Human Ecology Theory, following two hypotheses were formulated to be tested with empirical data. According to the problem of the present study, the study context considered to collect empirical data was the Customs Department of Sri Lanka.

$\mathbf{H}_{1}$ : There is a significant impact of work stress on work-life balance of employees.

H2: Work-life organizational support culture significantly moderates the impact of work stress on work-life balance.

\section{Conceptual framework}

The conceptual framework of the current study is depicted in figure 01. Work stress is considered as the independent variable while work-life balance is taken as the problem (dependent) variable. Work-life support organization culture (which prevails in Sri Lanka Customs Department) is assumed to be a moderator in the research model. The hypothesized relationships among constructs also shown in the same figure. 
Figure 01: Conceptual Framework of the Study

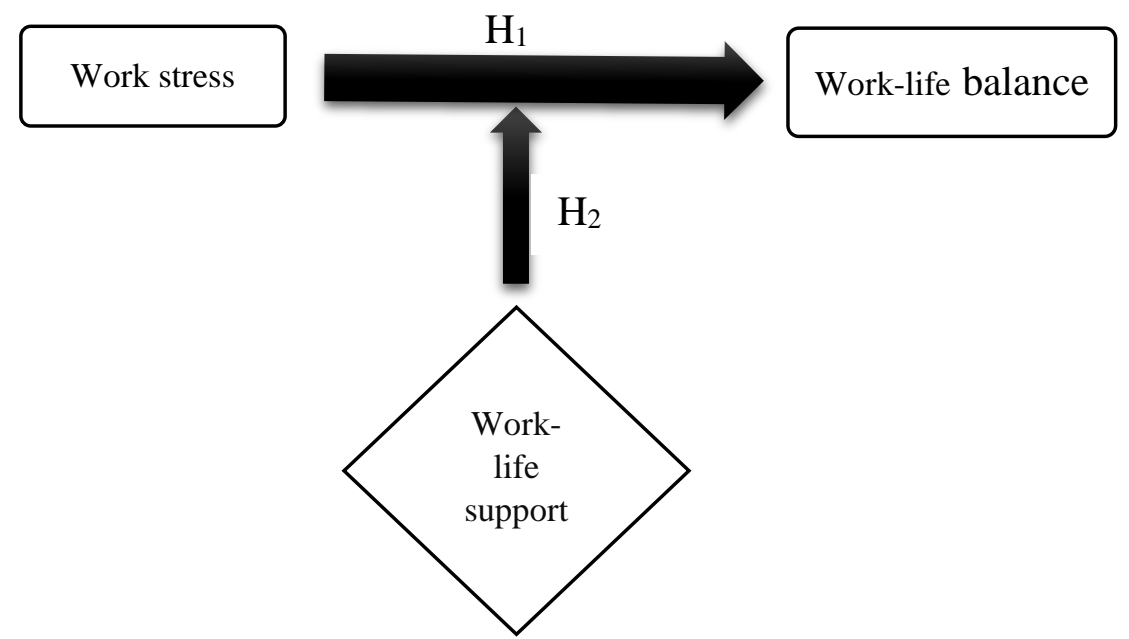

The independent variable; work stress is defined by Gruneberg (1979) as the harmful physical and emotional response that happens when there is a mis-match between demands of the job and capabilities or resources of the employee. Similarly, Cousins et al. (2004) defined the term stress as a pressing mental status in one's life due to an environmental reason/s which he mentioned as a multidimensional construct.

In the current research the working definition of work-life balance is taken from Greenhaus et al. (2003) in which work-life balance is defined as the degree to which an employee is appropriately engaged in, and as a result, contented with own life domains. Moreover, Greenhaus et al. (2003) discovered three (03) dimensions of work-life balance. They are: time balance; involvement balance and satisfaction balance.

Work-life support organizational culture is a culture in which employees are facilitated and encouraged to balance all the relevant domains of their lives up to the maximum potential level by recognizing the value of such a balance as a core value in the culture. Further to this working definition, Thomposon et al. (1999) identified three key elements in a work-life support organizational culture. They are: organizational demands on working time \& engagement and expectations 
about work and the family to be; career consequences associated with trying to achieve a balanced life; and managerial understanding, support \& sensitivity to employees' life and family responsibilities.

\section{Study design}

The study is a more basic research as the researchers attempted to answer a problem that is concerned with filling a contextual gap in the empirical knowledge having both theoretical and empirical values. Deductive approach was predominantly applied. The study is mainly explanatory. Similarly, this is a crosssectional, field study in which researchers' interference was minimum. The unit of analysis was at the individual level; a customer officer. Primary data was collected using a standard questionnaire through a survey.

\section{Population and the Sample}

The population concerned for the current study includes all the custom officers serving for Sri Lanka Customs Department; a total of 2018 officers (Annual Report of Sri Lanka Customs, 2017), from which the final sample was taken for the study. As the total number of respondents in the population is known, simple random sampling technique would be more appropriate to be used to select a representative sample (Saunders, Lewis \& Thornhill, 2009). A total of 200 custom officers was selected randomly from the headquarters of Customs Department which accounts nearly for $10 \%$ of the population.

\section{Measurement scales of variables}

\section{Work Stress}

Work stress was assessed using the measurement scale developed by Cousins et al. (2004) which was the most commonly used scale in the literature. This was appraised through six dimensions: demands, control, support, relationships, role and organizational change. The current researchers used 34 items fixed on a five point Likert scale adopted from Cousins et al. (2004) to assess work stress, and it had the average coefficient alpha of 0.91 in the original scale. Sample items include in the scale: ' I am pressured to work long hours' (demands); ' I can decide 
when to take a break' (control); 'There is friction or anger between colleagues' (relationships).

\section{Work-Life Balance}

The dependent variable work-life balance was assessed using the measurement scale (24 items) suggested by Thomas \& Ganster (1995). It was measured via three dimensions such as: time balance \& involvement balance (input balance), and satisfaction balance (output balance). Coefficient alpha for the original measurement scale was 0.88 . Custom officers were required to mention their level of agreement for the statements given on a five-point Likert scale fixed at $1=$ never and 5 = always. Sample items include:' I have a good balance between my job and my family time' (time balance), 'my job makes it difficult to be the kind of spouse or parent that I'd like to be' (involvement balance) and ' I feel emotionally weak when I get home from work' (satisfaction balance).

\section{Work-Life Support Organizational Culture}

Work-life support organizational culture was appraised through 18 items measurement scale which is suggested by Thompson, Beauvais \& Lyness (1999), and also widely used. A five point Likert scale anchored at $1=$ never and $5=$ always was employed as in the original scale. Alpha for the original scale obtained was 0.94 (Thompson, Beauvais \& Lyness, 1999). Sample items are: 'department is sensitive to our family and personal concerns' (managerial sensitivity and support), ' In this department employees who participate in available work-family programs are viewed as less serious about their careers than those who do not participate in these programs' (negative career consequences) and 'Employees are regularly expected to put their jobs before their families' (time demands and work expectations of the department).

\section{Data analysis tools and techniques}

The collected primary data was analyzed with the support of Microsoft Excel and Statistical Package for Social Sciences (SPSS) version 23.0. Frequency tables and descriptive statistics derived from SPSS were used to elaborate the sample composition and the individual behavior of three constructs. Reliability and the 
validity of measurement scales used, were ensured through an Exploratory Factor Analysis (EFA) and Cronbach's Alpha coefficient.

As this is a basic level quantitative research in which hypothetico-deductive reasoning is predominantly applied, moderated simple regression with SPSS is more appropriate to test the moderating effect of an organizational level variable (culture) than Structural Equation Modeling (SEM) in AMOS (Cousins et al, 2004). Hence, correlation analysis, simple regression analysis and the moderator regression analysis were done in the current study to test the formulated hypotheses and to come up with a conclusion.

\section{Results}

The final sample of the current study $(\mathrm{n}=188)$ consisted of $100.0 \%$ males $(\mathrm{n}=$ $188)$ and $0.00 \%$ females $(n=0)$, hence, this is a male dominant sample. Their age groups are from 24 to 42 years. The majority $(54.25 \%, \mathrm{n}=102)$ of the custom officers in the sample were married, and the remaining $45.75 \%(n=86)$ were single. Approximately $93.10 \%(n=176)$ of the respondents belonged to either the monthly income group of Rs. 75,000 - Rs. 100,000 or the more than Rs. 100,000 income group. Table 1 exhibits the demographic composition of the study sample.

Table 1: Demographic composition of the sample

\begin{tabular}{|l|l|c|c|}
\hline \multicolumn{2}{|c|}{ Variable } & Count & Percentage \\
\hline \multirow{3}{*}{ Gender } & Male & 188 & $100 \%$ \\
\cline { 2 - 4 } & Female & 0 & $0.00 \%$ \\
\hline \multirow{4}{*}{ Age } & Married & 102 & $54.25 \%$ \\
\cline { 2 - 4 } & Single & 86 & $45.75 \%$ \\
\hline & Less than 24 years & 0 & $0.00 \%$ \\
\cline { 2 - 4 } & $24-30$ years & 115 & $61.17 \%$ \\
\cline { 2 - 4 } & $30-36$ years & 47 & $25.00 \%$ \\
\cline { 2 - 4 } & $36-42$ years & 16 & $8.51 \%$ \\
\cline { 2 - 4 } & More than 42 years & 10 & $5.31 \%$ \\
\hline & Less than Rs. 50,000 & 0 & $0.00 \%$ \\
\hline
\end{tabular}




\begin{tabular}{|c|c|c|c|}
\hline \multirow{4}{*}{ Monthly Income } & $\begin{array}{l}\text { Rs. } 50,000 \text { - Rs. } \\
75,000\end{array}$ & 0 & $0.00 \%$ \\
\hline & $\begin{array}{l}\text { Rs. 75,000 - Rs. } \\
100,000\end{array}$ & 104 & $55.31 \%$ \\
\hline & $\begin{array}{l}\text { Rs. } 100,000 \text { - Rs. } \\
125,000\end{array}$ & 72 & $38.29 \%$ \\
\hline & $\begin{array}{l}\text { More than Rs. } \\
125,000\end{array}$ & 12 & $6.38 \%$ \\
\hline \multirow{5}{*}{ Job Seniority } & Less than 01 year & 13 & $6.91 \%$ \\
\hline & 01 - 03 years & 119 & $63.29 \%$ \\
\hline & 03 - 06 years & 11 & $5.85 \%$ \\
\hline & $06-10$ years & 39 & $20.74 \%$ \\
\hline & More than 10 years & 6 & $3.19 \%$ \\
\hline
\end{tabular}

\section{Source: Survey Data (2016)}

Internal consistency statistics were used to ensure the reliability of measurement scales (for each dimension and for each construct) which was assessed through the Cronbach's alpha coefficient with the aid of SPSS. Further, the data was tested for multivariate assumptions consisting the test for normality, linearity, multicollinearity and homoscedasticity before proceed with the hypotheses testing.

\section{Correlation analysis}

To examine the relationship between work stress of employees and work-life balance a scatter plot is constructed. According to the scatter plot linear relationship can be seen among two variables. As the relationship is linear, researcher used the 'Pearson Correlation Coefficient' to test the strength of the relationship among above mentioned two constructs/variables. As shown in table 2; Pearson Correlation Coefficient is -0.695 . It shows there is a strong negative relationship among work stress and work-life balance of the employee. Further, correlation coefficient is significant at the 0.01 level as sig (2-tailed) is less than 0.01 ; which is 0.000 . Hence, it can be statistically claimed that there is a significant negative relationship among work stress and work-life balance of custom officers. 
Table 2: Correlation statistics

\begin{tabular}{|l|l|r|r|}
\hline \multirow{3}{*}{$\begin{array}{l}\text { Work } \\
\text { Stress }\end{array}$} & Pearson Correlation & Work Stress & \multicolumn{1}{|c|}{ Work-life Balance } \\
\cline { 2 - 5 } & Sig. (2-tailed) & 1 & $-.695^{* *}$ \\
\cline { 2 - 4 } & $\mathrm{N}$ & 188 & .000 \\
\hline \multirow{2}{*}{$* *$ Correlation is significant at the 0.01 level (2-tailed). } \\
\hline
\end{tabular}

Source: Survey Data (2017)

\section{Regression analysis}

In the current research, moderated regression analysis was used to test the research model and develop the regression equation in steps (as recommended by Clark, 2002; Brown, 2004; Kim \& Gong, 2016). Then take the coefficient of partial determination to measure the marginal contribution of variables in the research model. Adjusted R Square values of computed two models are given in table 3.

Table 3: Model summary

\begin{tabular}{|l|r|r|l|l|}
\hline Model & \multicolumn{1}{l|}{ R } & R Square & Adjusted R Square & $\begin{array}{l}\text { Std. Error of the } \\
\text { Estimate }\end{array}$ \\
\hline 1 & $-.695^{\mathrm{a}}$ & .483 & .476 & .36233 \\
\hline 2 & $.716^{\mathrm{b}}$ & .512 & .481 & .35537 \\
\hline \multicolumn{5}{|l}{ a. Predictors: (Constant), Work stress } \\
\multicolumn{2}{|l}{ b. Predictors: (Constant), Work stress, Work life support culture } \\
\hline \multicolumn{2}{|l}{ c. Dependent Variable: Work-life balance } \\
\hline
\end{tabular}

Source: Survey Data (2017)

According to the model summary of table 3; the highest adjusted R Square is given by the second model. It means $48.10 \%$ of variation in dependent variable (worklife balance) is explained by the fitted regression model (which is moderated by the work-life support culture). To test the significance of the model following hypothesis was established.

H0: $\beta_{1}=\beta_{2}=0$

H1: At least one $\beta_{\mathrm{i}} \neq 0$

Where, $\beta_{1}$ and $\beta_{2}$ for work stress and work-life support culture respectively. 
Table 4: ANOVA

\begin{tabular}{|l|l|l|l|l|l|l|}
\hline \multicolumn{2}{|l|}{ Model } & $\begin{array}{l}\text { Sum of } \\
\text { Squares }\end{array}$ & df & $\begin{array}{l}\text { Mean } \\
\text { Square }\end{array}$ & F & Sig. \\
\hline \multirow{2}{*}{1} & Regression & 20.655 & 1 & 20.655 & 157.332 & $.000^{\text {a }}$ \\
\cline { 2 - 8 } & Residual & 10.240 & 78 & .131 & & \\
\cline { 2 - 7 } & Total & 30.895 & 79 & & & \\
\hline \multirow{2}{*}{2} & Regression & 21.171 & 2 & 10.585 & 83.817 & $.000^{\text {b }}$ \\
\cline { 2 - 7 } & Residual & 9.724 & 77 & .126 & & \\
\cline { 2 - 7 } & Total & 30.895 & 79 & & & \\
\hline \multicolumn{2}{|l|}{ a. Predictors: (Constant), Work stress } \\
\hline \multicolumn{7}{|l}{ b. Predictors: (Constant), Work stress, Work-life support culture } \\
\hline \multicolumn{7}{|l}{ c. Dependent Variable: Work-life balance } \\
\hline
\end{tabular}

\section{Source: Survey Data (2017)}

As per the table 4; the fitted second regression model is significant as Sig value is 0.000 which is less than 0.05 . Hence, $\mathrm{H}_{1}$ is accepted and it can be claimed that second regression model is significant than the first one which includes the moderator variable.

\section{Table 5: Coefficients}

\begin{tabular}{|c|c|c|c|c|c|c|}
\hline & \multirow{2}{*}{ Model } & \multicolumn{2}{|c|}{$\begin{array}{l}\text { Unstandardized } \\
\text { Coefficients }\end{array}$} & \multirow{2}{*}{$\begin{array}{l}\text { Standardized } \\
\text { Coefficients } \\
\text { Beta }\end{array}$} & \multirow{2}{*}{$\mathrm{t}$} & \multirow{2}{*}{ Sig. } \\
\hline & & B & $\begin{array}{l}\text { Std. } \\
\text { Error }\end{array}$ & & & \\
\hline \multirow{2}{*}{1} & (Constant) & .820 & .141 & & 5.820 & .000 \\
\hline & Work stress & -.695 & .061 & .818 & 12.543 & .000 \\
\hline \multirow{3}{*}{2} & (Constant) & .729 & .145 & & 5.011 & .000 \\
\hline & Work stress & -.626 & .089 & .673 & 7.028 & .000 \\
\hline & $\begin{array}{l}\text { Work-life } \\
\text { support culture }\end{array}$ & .139 & .069 & .194 & 2.021 & .047 \\
\hline
\end{tabular}

Source: Survey Data (2017) 
According to table 5; following hypotheses were formulated to test the analyzed data.

H0: $\beta_{0}=0$ Vs H1: $\beta_{0} \neq 0$

H0: $\beta_{1}=0$ Vs H1: $\beta_{1} \neq 0$

H0: $\beta_{2}=0$ Vs H1: $\beta_{2} \neq 0$

Where, $\beta_{0}, \beta_{1}$ and $\beta_{2}$ stand for constant value in the equation, work stress and worklife support culture respectively.

As sig values are less than 0.05 ; it can be conclude that constant is significant and should include in the final model. Similarly, $\beta_{1}$ and $\beta_{2}$ also significant and must be included in the final regression model. Thus $\mathrm{H}_{1}$ hypothesis of above is accepted. Following is the constructed regression equation; where $X_{1}$ stands for work stress and $\mathrm{X}_{2}$ stands for work-life support organizational culture. Work-life balance of employees' is given by $\grave{Y}$.

$\grave{Y}=0.729-0.626 X_{1}+0.139 X_{2}$

To ensure whether the constructed model is fitted the researchers did a residual analysis. Referring to the $\mathrm{P}-\mathrm{P}$ plot, as residuals are close to 45 diagonal line it can be said that residuals are approximately normally distributed. According to the scatter plot of standardized residuals derived in the residual analysis, points are randomly distributed and there is no pattern. Thus, the model is statistically adequate and can use to predict the variation in the dependent variable.

Having considered the aforesaid statistical evidence two alternative hypotheses $\left(\mathrm{H}_{1}\right.$ and $\left.\mathrm{H}_{2}\right)$ formulated in the present study were accepted. In conclusion, there are enough statistical evidence to claim that work stress is a significant predictor variables of work-life balance, and the work-life support culture exists in Sri Lanka Customs Department is found to be a significant moderator. It means work stress affect the work-life balance negatively. However, in a work-life support culture employees could achieve the work-life balance despite of the negativity coming from excessive stress. 


\section{Discussion of findings}

It was found that work stress significantly negatively associated with work-life balance of customs officers. Moreover, work-life support organizational culture was found to be a significant moderator. It was found that the direct relationship/impact of work stress on work-life balance is significantly moderated by the organizational culture that prevails in Sri Lanka Customs Department. Hence, it could be stated that even though the custom officers suffer from huge work stress as found in data analysis, they can enjoy a better balance between work and the life due to the organizational culture. So, the culture embodied in Sri Lanka Customs is the platform on which better work-life balance policies are being applied.

The found direct relationship and the impact of work stress and work-life balance has been long validated in several domains. For an example, Ernest \& Jama (2011); Guest (2001); Steven, Ngo \& Tsang (2010) and Wickramasinghe (2012) has obtained similar results. Ernest \& Jama (2011) and Guest (2001) explored the negative relationship between job stress and work-life balance of physical education teachers in Greece. Ngo \& Tsang (2010) found that job stress is correlated with low work-life balance and high propensity to leave. Further, Wickramasinghe (2012) found that one of the factors mostly influence work stress is work demands and time which in turn negatively affect the work-life balance of an employed person. Hence, it is noted that the current researcher has received similar results as found in literature.

The culture that exists in Sri Lanka Customs Department is found to be a worklife support culture as per the results of this study. That might be the reason customs officers are able to a certain extent balance their lives even though they engage in highly stressful, limitless, timeless and borderless work. In line with the findings of the current research, Clark (2000) found that organizational culture is most often linked with the facets of work-life balance. As Clark (2000) mentioned it is significantly correlated not only with job satisfaction of workers, but also with long term happiness in life. Further, Beauvais \& Kowalski (1993) found that worklife support organizational culture will reduce the amount and the gravity of inter- 
role conflicts. Similarly, Francesco \& Thompson (1996) found a culture in which employees are comfortable in balancing multiple demands facing a 'win-win' situation without sacrificing anything in life is as a proven expectation of new generations; generation $\mathrm{Y}$ and generation $\mathrm{Z}$. It is indeed a critical eye opening finding for employers, as they are the new comers to the world of work and hence, organizational cultures must be redesigned to welcome them and retain them.

\section{Conclusion}

Current research is distinctive in its clarification of the organizational culture regarding the balance between work and life and has made great practical experience. It is not considered the work-life support culture in explaining the impact of stress at work on balance between work and life in up to date literature. So, with empirical findings this would address the contextual gap in Sri Lanka Customs and the inadequacy of stress theories up to date.

The findings illustrate that the impact of work stress on work-life balance is moderated by the work life support of organizational culture. In particular, the existence of a culture of support in the field of employment is the main prerequisite for achieving the intended results of the so-called employment initiatives in Sri Lanka Customs. Hence, it could be concluded to establish and maintain such a culture at work to get the maximum expected outcome of implementing worklife balance initiatives and to manage the work stress of employees.

\section{Recommendations}

To obtain the expected results from work-life balance initiatives to its maximum, it is recommended for customs superiors and higher rank officers (the authority) in Sri Lanka Customs Department to nurture a work-life support organizational culture as an essential pre requisite. In such a culture employees could achieve an appropriate balance among work and the rest of life. Also, frequent employee training would be an effective way to develop employees' capacity to manage multiple expectations of multiple roles in their lives, convincing communication, proper delegation of work and the authority, allowing employees to prioritize two 
domains accordingly are some of the effective ways to foster such a culture in the work place.

In line with the extant literature, to develop employees' capacity to manage multiple expectations in multiple life domains, previous studies have also shown that organizations must create and maintain a culture in which workers are allowed to effectively discuss their jobs (Carlson et al., 2009), and supports them in their work and non-work pursuits (Chou \& Cheung, 2013).

\section{Directions for future research}

It is expected that future research studies will be carried out in the same domain, or might be in the Customs Department itself, should be initiated considering more outcome variables such as employee productivity, family satisfaction, and as well as other socio-cultural factors as moderators or mediators may increase the strength of the research model. Also, cross validation of the results in other organizations and industries is suggested. Furthermore, it is suggested that future studies should collect data from various data sources other than employees, such as: managers, team leaders/project leaders, subordinates, clients, spouses, children, and comparatively from a bigger sample as it would provide more solid and broader insights regarding the relationship between the variables considered in this research study.

However, within its boundaries, the current study successfully achieved its set objectives, and opened new possibilities for social investigations in the future. Hence, it is expected that future studies in other industries/markets/countries considering more variables, will add more value to the present research work in the field of Human Resource Management.

\section{References:}

Bailyn, L. (1993). 'Breaking the mold: Women, men and time in the new corporate world', New York: Free Press.

Barnett, R.C. \& Hyde, J.S. (2001). 'Women, men, work, and family', American Psychologist, 56, 781-796. 
Brown, P. (2004). 'Promoting work/life balance in a hurry culture: Issues and challenges', Retrieved October 05, 2009, from Griffith University website :www.gu.edu.au/ins/collections/proflects/brownp04.pdf.

Burke, R.J. (1988). 'Some antecedents and consequences of work-family conflict', Journal of Social Behavior and Personality, 3, 287-302.

Chana, X.W., Kalliatha, K., Broughb, P., Siuc, O.L., Driscolld, M.P. and Timmse, C. (2015). 'Work-family enrichment and satisfaction: the mediating role of selfefficacy and work-life balance', The International Journal of Human Resource Management.

Chou, K.L., \& Cheung, K.C.K. (2013). 'Family-friendly policies in the workplace and their effect on work-life conflicts in Hong Kong', International Journal of Human Resource Management, 24, 3872-3885.

Clark, S.C. (2001). 'Work culture and work-family balance', Journal of Vocational Behavior, 58, 348 - 365 .

Clark, S.C. (2002). 'Employees' sense of community, sense of control, and work/family conflict in Native American organizations', Journal of Vocational Behavior, 61, 92-108.

Clark, S.C. (2000). 'Work/family border theory: A new theory of work/life balance', Human Relations, 53, 6, 747-770.

David, Y.G., Syed, S.A., Zaini, A., \& Nilufar, A. (2009). 'A study of Job Stress on Job Satisfaction among university staff in Malaysia', European Journal of Social Sciences, 8, 1, 408 - 423.

Denison, D.R. (1996). 'What is the difference between organizational culture and organizational climate? A native's point of view on a decade of paradigm wars', Academy of Management Review, 21, 619-654.

Galea, C., Houkes, I., \& De Rijk, A. (2014). 'An insider's point of view: How a system of flexible hours helps employees to strive a proper balance between work and personal life', International Journal of Human Resource Management, 25, 8, 1090 - 1111. 
Galinsky, E., \& Stein, P.J. (1990). 'The impact of human resource policies on employees: Balancing work and family life', Journal of Family Issues, 11, 368383.

Greenhaus, J.H. (2006). 'When Work and Family are allies: A Theory of Work and Family Enrichment', Academy of Management Review, 31, 01, 72-92.

Greenhaus, J.H. and Powell, G.N. (2003). 'When and family collide: Deciding between competing role demands', Organizational behavior and human decision processes, 90, 291-303.

Guest, D.E. (2001). 'Perspective on the Study of Work - Life Balance', ENOP symposium, Paris, March 29-31: The Management Centre, King's College, London.

Hill, E.J., Hawkins, A.J. \& Miller, B.C. (1996). 'Work and family in the virtual office: perceived influence of mobile telework', Family Relations, 45, 293-301.

Hill, E.J., Miller, B.C., Weiner, S.P. and Colihan, J. (1998). 'Influences of the virtual office on aspects of work and work/life balance', Personnel Psychology, $51,683-67$.

Hyman, J. \& Summers, J. (2004). 'Lacking balance? Work-life employment practices in the modern economy', Personnel Review, 33, 4, 418 - 429

Igbaria, M. and Guimeraes, T. (1999). 'Exploring differences in employee turnover intentions and its determinants among telecommuters and nontelecommuters', Journal of Management Information Systems, 16,147-64.

Jaminson, L. and Morton, S. (2004). 'Work-life balance across the life course', CRFR Research Briefing.

Kanter, R.M. (1977). Work and family: A critical agenda for research and policy. New York: Russell Sage.

Kim, H. and Gong, Y. (2016). 'Effect of work-family and family-work conflicts on flexible work arrangements demand: A gender role perspective', International Journal of Human Resource Management. 
Kirchmeyer, C. (1992). 'Non-work participation and work attitudes: A test of scarcity vs. expansion models of personal resources', Human Relations, 45, 8, 775795.

Lambert, A.D., Marler, J.H. and Gueutal, H.G. (2008). 'Individual differences: Factors affecting employee utilization of flexible work arrangements', Journal of Vocational Behavior, 73, 107-117.

Lewis, C. (2000). A man's place is in the home: Fathers and families in the UK. York, Joseph Rowntree Foundation.

Limoges, J. (2003). 'A balanced work-life: A matter of maintenance', Food for Thought Document 11. Ottawa, ON: Canadian Career Development Foundation. McNall, L.A., Nicklin, J.M., \& Masuda, A.D. (2010). 'A meta-analytic review of the consequences associated with work-family enrichment', Journal of Business and Psychology, 25, 381-396.

Netemeyer, R., Boles, J. \& McMurrian, R. (1996). 'Development and Validation of Work-Family Conflict and Family-Work Conflict Scales', Journal of Applied Psychology, 81, 04, 400 - 410.

Opatha, H.H.N.D.P. (2015). Human Resource Management: Personnel. Colombo-Sri Lanka, Author.

Perlow, L.A. (1998). 'Putting the work back into work/family', Group and Organization Management, 20, 227-239.

Pocock, B. (2006). The Labour Market Ate My Babies: Work, children and A Sustainable Future. The Federation Press: Sydney.

Polach, J. (2003). 'HRD's role in work-life integration issues: moving the workforce to a change in mindset', Human Recourse Development International, 6, 1, 57-68.

Rizvi, I., Fernando, Y., \& Ishaq, M. (2013). 'The Impact of Contexual Factor on the Entreprenerial Intent of IT Undegraduates: A Sri Lankan Perspective', Sri Lankan Journal of Management, 18, 1 \& 2, 23 - 35. 
Rothausen, T.J. (1994). 'Job satisfaction and the parent worker: The role of flexibility and rewards', Journal of Vocational Behavior, 44, 317-336.

Rothbard, N.P. (2001). 'Enriching or Depleting? The Dynamics of engagement in work and family roles', Administrative Science Quarterly, 46, 11, 655-684.

Saunders, R., Lewis, P., \& Thornhill, A. (2011). Research Methods for Business Students, New Delhi: Dorling Kindersley (nida) Pvt. Ltd.

Shinn, M., Wong, N.W., Simko, P.A. \& Ortiz-Torres, B. (1989). 'Promoting wellbeing of working parents: Coping, social support, and flexible job schedules', American Journal of Community Psychology, 17, 31-55.

Sieber, S.D. (1974). Toward a theory of role accumulation, American Sociological Review, 39, 04, 567-578.

Sri Lanka Customs Department. (2015). Annual Report. Colombo, Sri Lanka: Sri Lanka Customs Department.

Thomas, L. \& Ganster, D. (1995). Impact of family supportive work variables on work family conflict and strain: A control perspective, Journal of Applied Psychology, 80, 01, 06 - 15.

Thompson, C., Beauvais, L. \& Lyness, K. (1999). 'When work-family benefits are not enough: The influence of work-family culture on benefit utilization, organizational attachment, and work-family conflicts', Journal of Vocational Behavior, 54, 392 - 415.

Van Eijnatten, F.M., \& Vos, J.P. (2002). Tautologies of work life balance. Retrieved October 04, 2009, from www.chaosforum. com/nieuws/ Tautologies. pdf.

Voydanoff, P. (1988). Toward a conceptualization of perceived work-family fit and balance: A demands and resources approach, Journal of Marriage and Family, 822-836.

Weerasinghe, T.D, \& Batagoda, C. K. (2011). Job Stress and Job Satisfaction: A Study of Managerial Employees in Domestic Commercial Banks. International Conference on Business and Information (ICBI) Proceedings (pp. 1 - 20). University of Kelaniya. 